\title{
I love me - Body Image Peer Mentor, Support and Leadership Program
}

\author{
Amanda Dearden ${ }^{*}$, Alison Lee \\ From 2015 ANZAED Conference: Riding the Waves to Recovery \\ Surfers Paradise, Australia. 21-22 August 2015
}

Isis- The Eating Issues Centre Inc. School Based Prevention and Early Intervention Evaluation

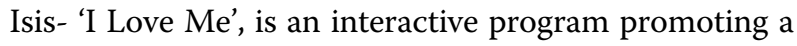
whole of school approach to promoting positive body culture using creative, interactive age appropriate activities and discussions. Quantitative and Qualitative evaluation of 6 pilot schools will be presented alongside learnings and recommendations.

Pre and post measures of students were evaluated $(\mathrm{n}=$ 110). 59 year ten, 38 year nine, 2 year eleven and 2 year twelve students participated comprised of females $53.6 \%$, males $29.1 \%$ with an age range from 13 to 17 . Control group included 36 and 74 completed the pilot program.

Qualitative measures indicated increase in students selfreported knowledge of body image; confidence in referring, ability to contribute to improved body image in others, increased satisfaction and acceptance of own body. Quantitative results include:

- The Sociocultural Attitudes scale showed a significant reduction in media influence across all of the subscales after Isis training, including significant decrease in body surveillance.

- The Empowerment scale showed an improvement in self-esteem, increased capability of achieving outcomes as a community, increased optimism and sense of control over the future.

Submit your next manuscript to BioMed Central and take full advantage of:

- Convenient online submission

- Thorough peer review

- No space constraints or color figure charges

- Immediate publication on acceptance

- Inclusion in PubMed, CAS, Scopus and Google Scholar

- Research which is freely available for redistribution
( Biomed Central

\footnotetext{
* Correspondence: amanda_dearden@isis.org.au
} Isis- the Eating Issues Centre Inc, Australia

(c) 2015 Dearden and Lee This is an Open Access article distributed under the terms of the Creative Commons Attribution License (http://creativecommons.org/licenses/by/4.0), which permits unrestricted use, distribution, and reproduction in any medium, provided the original work is properly cited. The Creative Commons Public Domain Dedication waiver (http://creativecommons.org/ publicdomain/zero/1.0/) applies to the data made available in this article, unless otherwise stated. 